\title{
ANALISIS STRUKTURAL TIGA CERPEN BERTEMA VIRUS KORONA
}

\author{
Muhajir \\ muhajir@upgris.ac.id \\ Universitas PGRI Semarang
}

\begin{abstract}
Every major event produces a masterpiece. The coronavirus (Covid) is a major event; the literary works born at that time are worthy of research. This study aims to trace the peculiarities of three short stories with the theme of Covid. This study uses a text analysis method with three short stories with the theme Corona, and the formal objects are structuralism and social criticism. The approach used is structuralism by examining facts and story tools with the descriptive-analytical method. The analysis results show that there are specificities in creating characters, styles, themes, satyr. First, the character deals with the occurrence of the coronavirus, such as victims and the virus spreading media. Second, dealing with style, the atmosphere of the three short stories understudied is gloomy and dark. Third, the theme deals with human greed, personal and group egos, and patriarchal culture, wherein the Corona situation affects the family, and the most impacting is the wife or woman. Fourth, satire is used to criticize human behavior for changing human consciousness.
\end{abstract}

Keywords: corona; short stories; story tools; story facts; satyr

Peristiwa besar biasanya melahirkan karya-karya besar. Demikian juga dengan korona, wabah yang berdampak sangat luas secara internasional. Sebuah peristiwa yang mengubah banyak hal, termasuk perilaku hidup, gaya belajar, dan model berinteraksi. Segala bidang terdampak oleh virus yang pertama kali muncul di WuhanCina ini. Peristiwa ini dimulai sejak pemberitaan yang mengerikan di Wuhan, dimana banyak korban mati di pinggir jalan, ditutupnya kota untuk menghindari meluasnya virus, hingga dibangunnya sebuah rumah sakit khusus korona dalam waktu singkat. Kabar-kabar itu menjadi teror ke seluruh dunia. Selanjutnya pemberitaan berlanjut, ditemukannya korona di negara lain, hingga 2 Maret 2020 terdapat kabar bahwa korona masuk di Indonesia (tim detik.com 2020). Setelah itu semuanya berubah, sekolah diliburkan, atau sekolah dari rumah, masjid-masjid ditutup, pasar-pasar dibatasi, hingga banyak karyawan pabrik diberhentikan sementara karena berhenti produksi, perjalanan 
wisata berhenti total. Idul Fitri yang di Indonesia biasanya dirayakan dengan meriah, kali ini terpaksa dirayakan dengan cara yang sangat sederhana.

Sejak saat itu cerpen-cerpen di koran memunculkan tema-tema korona. Sebagaimana sifat koran yang selalu menampilkan sesuatu yang aktual dan baru demikian juga dengan rubrik cerpen. Ada cerpen-cerpen yang hanya menyinggung sekilas tentang korona, ada cerpen-cerpen yang secara khusus mengetengahkan fenomena korona di dalam cerpen. Ada cerpen yang hanya menampakkan korona sebagai latar sedangkan konfliknya masalah lain, seperti cerpen berjudul Belukar Pantai Sanur karya Gde Aryantha Soethama (2020) yang menampilkan Bali di masa korona tetapi konflik sesungguhnya adalah masalah narkoba.

Cerpen bertema korona memiliki kekhasan dibanding dengan cerpen bertema lain. Kekhasan itu misalnya, tokoh-tokoh yang muncul dalam cerpen-cerpen bertema korona, alur, tema, latar, sudut pandang, dan simbolisme.

Dalam struktur terdapat fakta cerita yaitu tokoh, alur, tema, dan latar. Selain itu ada sarana cerita antara lain judul, sudut pandang, gaya, simbolisme, ironi. Sarana cerita menurut Stanton (2010) adalah metode yang dipakai pengarang dalam memilih dan menyusun detail cerita agar tercapai pola-pola yang bermakna. Hal ini penting diteliti karena setiap pilihan itu (sudut pandang, penokohan, latar, dll) menimbulkan efek yang berbeda-beda.

Objek material penelitian ini adalah tiga cerita pendek bertema korona. Tiga cerpen itu dipilih karena sesuai pembacaan peneliti memenuhi segi variasi data. Alasan lain adalah tiga cerpen ini bercerita khusus tentang korona karena banyak cerpen lain yang muncul pada era ini menempatkan korona hanya sebagai latar bukan sebagai persoalan mendasar.

Tiga cerpen itu adalah pertama, Simuladistopiakoronakra karya Seno Gumira Ajidarma (Ajidarma, 2020). Kedua cerpen berjudul Jalan sunyi menuju mati Karya Fandrik Ahmad (Ahmad, 2020). Ketiga Apa yang Paul McCartney Bisikkan di Telinga Janitra? Karya Sasti Gotama (Gotama, 2020).

Objek formal aspek cerpen ini adalah analisis struktural. Dengan menganalisis struktur tiga cerpen tersebut maka diharapkan akan diketahui kekhasan cerpen bertema 
Muhajir, Analisis Struktural Tiga Cerpen Bertema Virus Korona

korona dibanding cerpen bertema lain. Maka nanti akan dibaca secara mendetail unsurunsur intrinsik pembangun cerita. Dari pilihan sudut pandang, tiga penulis ini mengambil sudut pandang yang berbeda. Jika Seno melalui Simuladistopiakoronakra bercerita dari sudut pandang bukan manusia dan bukan virus. Makhluk yang ia buat adalah sosok keturunan manusia yang secara fisik bertubuh manusia dan berkepala ikan. Makhluk ini datang ke dunia untuk menyelamatkan bayi terakhir manusia. Manusia dalam cerita ini sudah tidak mampu menyelamatkan kaumnya sendiri. Bahkan bayi terakhir dari keturunan mereka juga akan dibunuh karena lahir bukan dari kelompoknya. Bahkan pada saat menjelang kepunahan pun, manusia masih memikirkan ego kelompok dan golongan.

Sedangkan Fadrik Ahmad melalui cerpen berjudul Jalan Sunyi Menuju Mati bercerita dari sudut pandang kelelawar, sebuah hewan yang dituduh menyebarkan virus. Dengan menggunakan sudut pandang orang pertama, 'aku' dalam cerita ini adalah kampret atau kelelawar. Sedangkan cerpen terakhir Apa yang Poul McCartney Bisikan di Telinga Janitra? Mengambil sudut pandang korban. Tokoh-tokoh dalam cerita ini adalah korban terdampak korona, contohnya, seorang suami yang dipecat dari pekerjaanya, seorang perempuan yang menjadi korban kekerasan karena menjadi pelampiasan suaminya yang frustasi karena dipecat dari pekerjaan. Variasi juga tampak pada kritik atau pesan penulis dan akan diceritakan lebih rinci nanti di pembahasan.

Dengan banyaknya kemunculan cerpen yang bertemakan korona menimbulkan pertanyaan apakah terdapat ciri khas cerpen yang bertemakan korona? Tujuan penelitian ini adalah dalam rangka mendeskripsikan ciri khas yang ada dalam setiap cerpen bertemakan korona.

\section{METODE PENELITIAN}

Penelitian ini menggunakan paradigma kualitatif dengan metode struktural. Data dikumpulkan melalui teknik simak dan catat untuk menemukan ciri-ciri tertentu yang ada pada setiap cerpen melalui analisis struktural. Teori struktural adalah sebuah teori yang menempatkan karya sastra sebagai sebuah keutuhan. Menurut Teeuw (1984) Karya sastra sebagai suatu struktur maka dapat dibongkar, dipaparkan secermat dan 
semendalam mungkin dan dapat dicari pula keterjalinan antar unsur yang dipandang dapat menghasilkan makna menyeluruh.

Implikasi dari teori yang digunakan maka metode yang digunakan adalah menguraikan unsur-unsur intrinsik di dalam cerpen, maka secara berurutan akan dibahas fakta cerita dan sarana cerita tiap-tiap cerpen. Menurut Pradotokusumo (2002:16) dalam Aprianti, dkk., 2015:2) tujuan penggunaan sarana cerita adalah untuk memungkinkan pembaca melihat fakta sebagaimana yang dilihat pengarang, menafsirkan makna fakta sebagaimana yang ditafsirkan pengarang, dan merasakan pengalaman seperti yang dirasakan pengarang.

\section{HASIL DAN PEMBAHASAN}

\section{Hasil Penelitian}

Dari hasil analisis struktural diperoleh hasil tentang ciri dari ketiga cerpen sebagai berikut.

\section{Tabel 1 Hasil Analisis Struktural}

\begin{tabular}{|c|c|c|c|c|}
\hline Judul Cerpen & Peran Tokoh & Gaya & Tema & Satire \\
\hline $\begin{array}{l}\text { Jalan Sunyi } \\
\text { Menuju Mati }\end{array}$ & $\begin{array}{l}\text { Kelelawar } \\
\text { sebagai sebab } \\
\text { virus korona }\end{array}$ & $\begin{array}{l}\text { Gelap } \\
\text { digambarkan } \\
\text { dengan darah dan } \\
\text { kekerasan. }\end{array}$ & $\begin{array}{l}\text { Keserakahan } \\
\text { manusia. }\end{array}$ & $\begin{array}{l}\text { Satire digunakan } \\
\text { untuk melancarkan } \\
\text { kritik terhadap } \\
\text { perilaku manusia } \\
\text { melalui cara } \\
\text { menyindir } \\
\end{array}$ \\
\hline $\begin{array}{l}\text { Simuladistopiak } \\
\text { oronakra }\end{array}$ & $\begin{array}{l}\text { Penyelamat } \\
\text { manusia yang } \\
\text { terancam punah } \\
\text { karena korona }\end{array}$ & $\begin{array}{l}\text { Gelap dan banyak } \\
\text { adegan } \\
\text { perkelahian. }\end{array}$ & $\begin{array}{l}\text { Keserakahan } \\
\text { manusia, ego } \\
\text { yang tinggi. }\end{array}$ & $\begin{array}{l}\text { Satire digunakan } \\
\text { untuk melancarkan } \\
\text { kritik terhadap } \\
\text { perilaku manusia } \\
\text { melalui cara } \\
\text { menyindir } \\
\end{array}$ \\
\hline $\begin{array}{l}\text { Apa yang Paul } \\
\text { McCartney } \\
\text { Bisikkan di } \\
\text { Telinga Janitra? }\end{array}$ & $\begin{array}{l}\text { Keluarga } \\
\text { terdampak } \\
\text { korona }\end{array}$ & $\begin{array}{l}\text { Pertengkaran } \\
\text { keluarga } \\
\text { terdampak korona. } \\
\text { Terdapat } \\
\text { kekerasan terhadap } \\
\text { perempuan. }\end{array}$ & $\begin{array}{l}\text { Relasi suami } \\
\text { istri yang tidak } \\
\text { seimbang, } \\
\text { adanya wabah } \\
\text { terdampak pada } \\
\text { perempuan } \\
\text { dalam keluarga. }\end{array}$ & - \\
\hline
\end{tabular}


Muhajir, Analisis Struktural Tiga Cerpen Bertema Virus Korona

\section{PEMBAHASAN}

\section{Jalan Sunyi Menuju Mati}

A. Tokoh

Pertama, tokoh dan penokohan atau kareakterisasi. Seorang tokoh cerita menurut Abrams, (dalam Fananie, 2002) dapat dilihat dari apa yang dikatakan dan apa yang dilakukan. Menurut Fananie (2000), terdapat dua cara untuk mendeteksi tokoh cerita, pertama adalah dengan melihat tampilan fisik. Di sini pengarang mengenalkan kepada pembaca di awal cerita tentang gambaran fisik tokoh, ciri-ciri khususnya, perilaku, latar belakang, keluarga, dan kehidupan tokoh. Kedua, pengarang tidak mendeskripsikan karakter tokohnya. Tokoh dikenali dari apa yang dilakukan, keputusan-keputusannya, pendapat tokoh lain terhadap tokoh tersebut.

Tarigan (2008: 149) membagi tokoh menjadi tiga; tokoh utama, tokoh penunjang, dan tokoh latar belakang. Tokoh utama adalah tokoh yang muncul dalam serangkaian cerita baik sebagai pemenang maupun kalah, sedangkan tokoh penunjang adalah tokoh yang perilaku dan perkataannya bertentangan dengan tokoh utama. Sementara tokoh latar belakang adalah tokoh yang memberikan ilusi atau bayangan dunia nyata (Tarigan, 2008).

Cerpen ini dimulai dengan mengenalkan tokoh utama, ciri-cirinya, latar belakangnya, dan perilakunya.

"Aku memang meminta kepada Tuhan agar bangsaku dilahirkan dalam keadaan buruk rupa. Rupa yang menyeramkan. Rupa yang menjijikkan. Rupa yang membuat bulu kuduk merinding. Aku juga meminta kepada Tuhan agar anak-anakku dilahirkan dalam keadaan tidak sempurna penglihatannya agar mereka tidak terbebani dengan nasibnya sendiri. Permintaanku kepada Tuhan bukan tanpa alasan. Sebagai bagian dari darah dan dagingku, tentu aku juga akan mewariskan ribuan penyakit yang bertakhta di sepanjang aliran darahku." (Ahmad, 2020).

Tidak hanya ciri-ciri fisiknya saja tetapi juga perilakunya sebagaimana tergambar sebagai kutipan berikut:

"Mencari makan di waktu malam. Istirahat di waktu siang. Sepasang sayap tipis yang dihadiahi Tuhan sangat membantu kami terbang di kesunyian malam. Apabila matahari telah menyumbulkan cahayanya, di situlah sepasang sayap tipis ini beralih fungsi menjadi pelindung diri. Kami istirahat.” (Ahmad, 2020). 
Tokoh utama dalam cerpen ini disebutkan langsung oleh pengarang. Ia menyebut tokoh ini disebut codot atau kampret.

Sedangkan tokoh penunjang dalam cerita ini adalah seorang yang kerap melakukan percobaan di laboratoriumnya dengan menggunakan hewan sebagai bahan percobaannya. Tokoh latar belakang di dalam cerita ini adalah para pedagang hewan di pasar.

B. Alur

Alur yang digunakan di dalam cerita ini adalah alur maju. Sebagaimana dikatakan oleh Nurgiantoro (2010:13) alur maju atau alur progresif adalah ketika peristiwaperistiwa yang dikisahkan bersifat kronologis, peristiwa yang pertama diikuti atau menyebabkan peristiwa berikutnya (Nurgiantoro 2010).

Cerita dalam cerpen ini dimulai dengan paparan dan dikenalkan tokoh dan tempat terjadinya peristiwa. Di sana diceritakan bahwa sang tokoh tinggal di tempat yang gelap dan sunyi dan tanpa cahaya. Pada tahap ini juga sudah dijelaskan bahwa alasan tokoh ini bersembunyi di tempat gelap adalah karena dia sadar di dalam tubuhnya terdapat ribuan virus. Sikapnya yang memilih sembunyi adalah sumbangsihnya terhadap kelestarian manusia.

Pada paragraf kesembilan baru rangsangan muncul. Pada saat si tokoh membahas bahwa nama codot atau kampret tidak hanya disematkan ada kaum mereka tetapi juga pada orang yang mencuri pada malam hari. Mereka memiliki pola hidup yang sama yaitu bekerja di kegelapan. Tetapi menurut si tokoh kaum mereka berbeda, jika hewan codot mengambil buah pada malam hari itu demi melanjutkan rantai makanan, berbeda dengan para pencuri itu mereka tidak hanya untuk memenuhi kebutuhan pangan tetapi juga untuk ditumpuk dan disimpan.

Gawatan muncul pada adegan di sebuah pasar hewan. Pada pasar itu digambarkan para pekerja memotong-motong tubuh hewan, golok yang kotor oleh darah dibersihkan dengan air di ember. Di sana hewan-hewan seperti musang, anjing, ular, terkapar tidak berdaya. Ada yang sudah mati dan ada pula yang terjerat tali putus asa. Di sini ada persitiwa tokoh penunjang (manusia peneliti) membeli tokoh utama (codot) untuk bahan percobaan. 
Muhajir, Analisis Struktural Tiga Cerpen Bertema Virus Korona

Bagian tengah pada alur adalah tikaian, rumitan, dan klimaks. Tikaian ini muncul ditandai dengan si codot yang meraung berusaha melepaskan diri, Ia ingat anaknya. “Anakku di mana anakku." Ia tidak berdaya di dalam kotak kaca. Rumitan ditandai dengan keaadaan ketika codot tidak berdaya dan membiarkan virus di dalam tubuhnya akan keluar mencari inang baru.

Klimaks cerpen ini adalah ketika ribuan virus keluar dari tubuh codot dan menempel di benda-benda di laboratorium.

"Ribuan virus terbang bebas. Hinggap pada pakaian hazmat dan benda-benda di sekitar. Aku turut bermoksa. Menjadi zarah tak kasatmata. Menjadi bagian dari mereka. Aku bisa menyaksikan tubuhku terbujur kaku. Teronggok tak berdaya. Kedua lelaki itu terus bermain-main dengan tubuhku." (Ahmad, 2020)

Setelah itu cerpen menuju bagian akhir leraian dan selesaian. Virus mulai menyebar melalui tokoh penunjang. Ia terbatuk-batuk di antara kerumunan. Nafasnya tersengal, setiap helaian nafas seperti mereguk bara. Akhirnya ia tumbang dan virus menyebar mencari inang baru. Si codot berkeliling mencari anaknya hingga belahan dunia lain. Ia sampai juga ke sebuah negara adikuasa yang ternyata tidak kuasa menghadapi virus. Ia sampai juga di negara yang suka menggoreng berita palsu. Akibat dari menyebarnya virus itu: seorang anak kelaparan. Seseorang ibu marah tak karuan. Seorang ayah kehilangan pekerjaan. Seorang kekasih merindukan belaian. Mereka tak mau bersalaman.

C. Latar

Latar tempat dan latar waktu yang digunakan di dalam cerita ini adalah ruang gelap tempat para codot bersembunyi pada malam hari, pasar hewan liar, laboratorium pada siang hari. Sedangkan latar sosial ditunjukkan bahwa codot adalah hewan yang inferior. Ia menyingkir dengan bentuk tubuhnya yang aneh dan laku hidupnya yang berbeda dengan makhluk biasanya.

Selanjutnya adalah tentang sarana cerita yang terdiri atas judul, sudut pandang, gaya dan tone, simbolisme, ironi, dan tema. Judul cerita ini adalah Jalan Sunyi Menuju Mati. Judul ini menggambarkan keadaan tokoh utama menjelang kematiannya. Ia menyingkir dari keramian karena sadar di dalam tubuhnya terdapat ribuan virus. 
D. Sudut Pandang

Cerpen ini menggunakan sudut pandang orang pertama utama yaitu tokoh utama yang bercerita. Melalui 'akuan' pembaca diajak ke tone yang sunyi, gelap, dan mencekam. Pasar yang bisanya ramai di sini digambarkan dengan peristiwa tukang jagal memotong-motong daging hewan yang darahnya mengalir ke mana-mana. Simbolisme terlihat ketika codot yang hewan juga digunakan untuk menyebut manusia pencuri.

E. Tema

Tema cerpen ini adalah keserakahan manusia. Dengan cara sindiran disampaikan sejak awal cerita di mana codot yang sadar telah mengemban banyak virus memilih tempat yang sepi dan jauh dari kehidupan manusia. Hal itu dia lakukan tidak lain demi sumbangsihnya terhadap kemanusiaan. Cerpen ini mengkritik keserakahan manusia, hewan yang sudah bersembunyi saja tetap diburu dan diperjualbelikan. Keserakahan juga ditunjukkan oleh manusia yang berperilaku codot, bekerja pada malam hari untuk mencuri. Jika codot melakukan itu hanya dikarenakan naluri kehewanannya untuk memenuhi kebutuhan makan sebagai kebutuhan primer, manusia melakukannya karena sifat serakah.

F. Satire

Ego, keserakahan manusia diungkapkan dengan cara satire. Karakteristik satire menurut Palmeri sebagaimana dikutip oleh Dewi (2017) ada tiga. Pertama, kritik. Satire selalu merupakan kritik atas perilaku manusia yang buruk atau bodoh dengan tujuan mengajak penonton melihatnya dan mencibirnya, yang akan mendorong pada perubahan sosial. Kedua, ironi. Satire menggunakan ironi, seringkali dengan cara humor, untuk menunjukkan masalah-masalah perilaku yang dikritik. Ketiga, hal tersirat. Satire bukanlah pernyataan yang terbuka dan tidak disampaikan dengan cara terbuka, tetapi lebih kepada kritik untuk mengubah perilaku melalui karya satire dengan menjadi sangat tidak masuk akal, seringkali karena dilebih-lebihkan atau di luar konteks normal.

Dalam cerpen ini satire dilakukan dengan menggunakan tokoh kampret atau kelelawar. Ia sudah menyingkir, tetapi manusia rakus sehingga kelelawar yang sudah bersembunyi karena ambisi manusia tetap diburu juga. Satire juga muncul untuk 
Muhajir, Analisis Struktural Tiga Cerpen Bertema Virus Korona

menyindir manusia yang berperilaku kampret, bekerja mencuri pada malam hari. Satire ditunjukkan seperti kutipan berikut ini.

Manusia-manusia yang terbelalak mengais rezeki di sepanjang malam, di jalan-jalan kelam nan sunyi, sering dikaitkan dengan kami. Bedanya, kami terbang di antara reranting, sementara mereka merayap di antara pagar dan tembok tetangga (Ahmad, 2020).

\section{Simuladistopiakoronakra}

\section{A. Tokoh}

Cerpen karya Seno Gumira Ajidarma ini menghadirkan tokoh utama yang unik. Ia adalah keturunan manusia tetapi bukan manusia. Ia telah dilamar oleh bangsa ikan untuk menjadi bagiannya. Secara fisik tokoh yang tidak diberi nama ini bertubuh manusia tetapi berkepala ikan. Tokoh utama ini tinggal di tempat antah berantah dan pindah dari satu galaksi ke galaksi lain. Deskripsi tentang tokoh sebagaimana kutipan berikut.

“Aku bertubuh, berkaki, dan bertangan seperti manusia, tetapi berkepala ikan. Punggungku bersirip, kulitku bersisik, dan ruang di antara jari-jariku berselaput. Seperti ikan, dunia kulihat dari sepasang mata yang memandang ke B. Alur

arah berlawanan." (Ajidarma, 2020).

Alur cerpen ini dimulai dengan kedatangan manusia berkepala ikan ini ke bumi. Ia menyaksikan bumi yang berbau apak. Ia katakan jika bukan karena tugas hal itu tidak mungkin dia lakukan. Ketika dia datang bumi dalam keadaan rusak, panas, dan berdebu, selokan kotor, laut kering. Makhluk bumi sudah hampir punah. Mereka berbujur kaku tidak bergerak karena menderita Covid 44. Bumi sebagai latar cerpen ini digambarkan sebagaimana kutipan berikut ini: "Apalah yang masih bisa diharapkan dari Bumi yang samudranya kering, sungainya berhenti, menyisakan selokan mampat dengan air kehitam-hitaman?" (Ajidarma, 2020).

Tugas manusia berkepala ikan adalah menyelamatkan bayi terakhir yang ada di bumi demi kelangsungan manusia. Selain tokoh manusia berkepala ikan ada juga tokoh komandan. Komandan adalah sosok yang memberi tugas dan memberi instruksi bagi manusia berkepala ikan. Kemudian tokoh penunjang yang berposisi sebagai lawan, ia 
selalu berperilaku berlawanan dengan tokoh utama dan selalu ingin menggagalkan misi tokoh utama adalah manusia. Jika tugas tokoh utama adalah untuk menyelamatkan bayi terakhir maka tugas tokoh penunjang adalah sebaliknya, ia akan membunuh bayi terakhir itu. Tokoh penunjang adalah keturunan manusia yang masih menjadi manusia. Alasan tokoh penunjang ini ingin membunuh bayi terakhir karena bayi itu tidak lahir dari keturunannya. Ego besar manusia untuk salaing bersaing meski dalam ambang kepunahan masih terlihat di sini.

"Wabah itu tidak pernah menjadikan manusia menunda pertentangan mereka untuk menghadapi musuh bersama," kata Komandan lagi, "selamatkanlah yang masih bisa diselamatkan, karena kepunahan telah menjadi kepastian...." (Ajidarma, 2020)

"Hai kepala ikan serahkan bajumu" hal itu dikatakan manusia-manusia yang sekarat. Baju rombeng milik kepala ikan masih saja dia minta. Kalimat tersebut menandai rangsangan. Karena setelah itu penjelasan tentang tokoh lebih didetailkan. Adegan masuk ke gawatan ketika kepala ikan diserang akan dibunuh. Konflik terjadi ketika terjadi adegan perkelahian antara manusia berkepala ikan dengan manusia. Sampai puncaknya manusia kepala ikan berhasil menaikkan bayi terakhir manusia ke angkasa tetapi nasib naas tertimpa manusia berkepala ikan karena harus meregang nyawa, tubuhnya terkena senjata lawan.

Manusia berpasangan untuk dapat berkembang biak. Padahal bayi yang diselamatkan hanya satu, bagaimana keberlangsungan bisa tetap terjaga? Sebelum mati tokoh utama sempat berpikir: "Sempat terpikir olehku betapa kemanusiaan akan terpaksa dipertahankan dengan cara kloning...."

C. Latar

Latar waktu dan latar tempat telah disebutkan di atas, kali ini kita akan membahas latar sosial. Latar sosial adalah posisi tokoh utama dalam masayarakat yang ada di dalam cerita. Masyarakat atau lingkungan yang ada dalam cerita ini adalah semesta yang disana terdapat makhluk-makhluk seperti manusia dan makhluk lain di galaksi lain. Manusia berkepala ikan sebagai tokoh utama ia tidak memiliki temat tinggal pasti. Ketika dia di bumi ia dianggap sosok yang layak dijarah, dirampok bajunya, dan dimakan tubuhnya. Sedangkan ketika dia ke galaksi lain ia juga disingkirkan karena 
Muhajir, Analisis Struktural Tiga Cerpen Bertema Virus Korona

takut menyebarkan virus kebodohan. Oleh penduduk planet lain, manusia memang dikenal bodoh sebagaimana kutipan berikut:

“...... betapa suatu wabah yang sebetulnya bisa diputus dengan mudah ratusan tahun lalu, karena sikap meremehkan telah menghabiskan seluruh pemukimnya, enam miliar manusia, selain yang masih sekarat sekarang dan tiada jelas kapan akan berpulang." (Ajidarma, 2020).

Berikutnya adalah pembahasan sarana cerita, yakni terutama pada judul cerpen. Judul cerpen ini adalah Simuladistopiakoronakra, sebuah judul yang tidak lazim dan secara bahasa tidak bisa dilacak arti judul itu. Tetapi di dalam judul itu terdapat kata korona maka dari itu cerpen ini bisa langsung dikaitkan dengan virus yang sedang mewabah sekarang ini. Di dalam cerita wabah virus korona disinggung beberapa kali. Digambarkan bagaimana manusia menghadapi virus, mulai Covid 19 hingga Covid 44 manusia tetap saja bertengkar dan tidak tahu menyelesaikan masalah secara bersamasama. Hingga mereka tidak sadar mereka menuju punah.

D. Sudut Pandang

Cerpen ini menggunakan sudut pandang orang pertama utama, artinya cerpen diceritakan dari tokoh utama. Hal ini menjadi unik karena pencerita yang sekaligus tokoh utama ini bukanlah manusia. Ia diciptakan untuk menyindir sifat serakah manusia. Dari pencerita ini kita bisa saksikan posisi manusia di mata makhluk lain di seluruh dunia. Sudut pandang orang pertama sudah biasa digunakan dalam penceritaan, menjadi unik karena tokohnya yang beda.

E. Gaya

Gaya atau tone cerita adalah mencekam dari awal sampai akhir. Suasana perkelahian antara tokoh utama dengan tokoh penunjang terjadi dari awal sampai akhir cerita. Adegan-adegan penuh darah, tebasan pedang, terbang, meluncur, memukul terjadi di sepanjang cerita.

Simbolisme hadir melalui tokoh utama; manusia berkepala ikan. Tokoh ini diciptakan untuk mengejek manusia bumi yang tidak bisa menyelamatkan diri dan kaumnya. Mereka terus bertengkar meskipun menjelang kepunahan. Wabah dan bencana yang terjadi tidak menjadikan manusia bersatu untuk mengatasi musuh bersama.

Copyright (C) 2021 Muhajir 
F. Tema

Tema cerpen ini adalah tema sosial karena yang menjadi titik kritik adalah masalah sosial seperti keserakahan manusia, ego manusia baik ego pribadi maupun ego kelompok. Justru yang memiliki pikiran untuk menyelamatkan keberlangsungan manusia bukanlah manusia sendiri tetapi makhluk lain; manusia berkepala ikan.

G. Satire

Karya ini sebenarnya adalah sebuah kritik menggunakan satire terhadap perilaku manusia dalam menyikapi lingkungan, dalam menghadapi wabah. Karena ego pribadinya manusia lupa caranya bekerja sama untuk menyelesaikan wabah. Satire dilakukan dengan cara sindiran, pembaca dalam hal ini manusia ketika membaca akan merasa dibicarakan. Satire bertujuan menjadikan perubahan kesadaran dan perubahan sosial.

\section{Apa yang Paul McCartney Bisikkan di Telinga Janitra?}

Cerpen ketiga atau terakhir adalah sebuah cerita yang berjudul Apa yang Paul McCartney Bisikkan di Telinga Janitra? Seperti kedua cerpen sebelumnya cerpen ini dibahas tentang fakta ceritanya baru kemudian sarana cerita.

\section{A. Tokoh}

Tokoh utama dalam cerita ini adalah seorang perempuan ibu rumah tangga bernama Janitra. Janitra adalah seorang ibu rumah tangga yang memiliki satu orang anak yang belum bisa bicara lancar. Ia sebelumnya bekerja, tetapi karena suami menuntut mengurus anak dan menyalahkan ketika Nara, anaknya belum bisa bicara akhirnya Janitra keluar dari pekerjaannya.

Masalah muncul karena selang beberapa saat ketika Janitra keluar dari pekerjaannya, Virus korona datang. Gupta yang bekerja di bidang perhotelan terkena dampak. Hotel sepi pengunjung sehingga manejemen tidak bisa membayar gaji karyawan. Dalam cerita ini Gupta adalah tokoh penunjang. Keberadaannya berhadaphadapan dengan Janitra sang tokoh utama.

Gupta adalah sosok yang egois. Ia mau menang sendiri dan tidak mau disalahkan. Ia menyalahkan Janitra ketika anaknya tidak terurus. Tetapi dia juga menyalahkan Janitra ketika Janitra keluar dari pekerjaannya. Gupta ingin keduanya bisa berjalan Copyright $\odot 2021$ Muhajir 
Muhajir, Analisis Struktural Tiga Cerpen Bertema Virus Korona

seiring dan tidak meninggalkan salah satunya; pekerjaan rumah beres dan juga bekerja di luar rumah. Hal tersebut menurut Janitra tidak mungkin dilakukan.

Gambaran konflik itu bisa dilihat dari dialog berikut ini:

"Aku tak pernah menyuruhmu berhenti. Aku hanya mengatakan, Nara butuh perhatian. Kau bisa menyisihkan waktu lebih banyak di rumah. Bukannya lembur dengan tikus-tikus putih itu! Kalau kau ingin Nara bisa bicara, harusnya kau lebih sering bersamanya!"

"Di lab, aku punya tanggung jawab. Aku tak bisa terus-terusan izin atau pulang lebih awal."

"Nara tanggung jawabmu! Kau ibunya!"

"Itu berarti kau tak memberiku pilihan. Sama saja kau memintaku berhenti."

"Itu pilihanmu sendiri!" (Gotama, 2020)

Nara adalah tokoh latar belakang. Satu lagi tokoh latar belakang, ia berada di pihak Janitra, ia disebut Si Kumbang. Si Kumbang ini selalu keluar dari tubuh Janitra ketika emosi Janitra memuncak. Si Kumbang ini semacam harimau, matanya merah, berkuku tajam, dan berekor panjang. Namun Janitra ini selalu meredam kemunculan Si Kumbang karena dia tidak ingin dua orang yang ia sayangi, Gupta dan Nara menjadi korban. Cara meninabobokkan Si Kumbang adalah dengan cara mendengarkan sesuatu yang ritmis dan mendengarkan sebuah lagu berjudul "Let It Be" yang dibawakan oleh Paul McCartney.

Satu hal lagi yang perlu mendapatkan perhatian yaitu cara Sasti memberi namanama tokoh-tokohnya. Janitra, Nara, dan Gupta. Penamaan tokoh ini tidak biasa karena secara budaya, Indonesia misalnya nama tersebut tergolong tidak biasa.

B. Alur

Alur cerpen ini adalah alur maju dan dapat dibagi menjadi tiga tahap. Tahap pertama adalah pengenalan tokoh sekaligus mengenalkan pula masalahnya. Peristiwa menuju klimak adalah perdebatan tentang pekerjaan. Gupta dipecat dari pekerjannya dan menyalahkan Janitra yang keluar kerja. Ada peristiwa Gupta menampar Janitra di sini.

Tahap kedua adalah tahap tengah yang menjadi klimaks cerita. Saat itu Janitra sedang menenangkan diri karena selalu disalahkan oleh suaminya. Ia memotongCopyright $\odot 2021$ Muhajir 
motong wortel dengan suara ritmis, ia nyalakan kran air dengan suara ritmis pula dan melantunkan lagu "Let It Be". Sementara itu anaknya sudah bangun. Apa yang dilakukan oleh Janitra itu membuat Gupta marah. "Nara sudah bangun! Apa kau tuli? Ia menangis keras sekali! Dan satu lagi, hentikan lagu bodoh itu! Kau membuatku pusing!" Gupta sudah berdiri tegak di pintu dapur dengan tangan terkepal.”

Pada saat itu pula si Kumbang yang ada di dalam tubuh Janitra keluar. Kemudian alur menuju tahap ketiga, tahap penyelesaian. Janitra memilih pergi dari rumah meninggalkan suami dan anaknya. Ia tidak pedulikan teriakan suaminya dan tangis anaknya. Janitra berjalan jauh dan duduk di bawah pohon sambil mendendangkan lagu untuk meredakan si Kumbang agar kembali tidur.

Konflik eksternal dalam cerita ini adalah persinggungan antara tokoh utama dengan tokoh penunjang, sedangkan konflik sosial menjadi latar belakang; terjadinya korona berdampak pada ekonomi dan berdampak pada keluarga.

C. Latar

Untuk latar waktu tidak diceritakan secara mendetail. Cerita ini dimulai pada waktu pagi saat anaknya masih tidur dan suami telah berangkat kerja. Sedangkan latar tempat, cerita ini hanya berkutat perdebatan rumah tangga di dalam rumah. Sedikit diceritakan tentang laboratorium tempat Janitra dulu bekerja. Latar sosial menunjukkan bahwa tokoh-tokoh dalam cerita ini adalah para buruh, para pekerja yang berada di garis bawah. Mereka rentan terhadap fluktuasi ekonomi karena tidak memiliki cadangan tabungan. Ketika mereka lepas dari pekerjaan, mereka hanya kuat bertahan selama satu bulan. Situasi ini membuat mereka panik dan terjadilah pertengkaran keluarga.

Pada tahap selanjutnya adalah tentang sarana cerita. Pertama tentang judul. Sasti memberi judul ceritanya Apa yang Paul McCartney Bisikkan di Telinga Janitra? Judul menggunakan kalimat tanya menimbulkan rasa ingin tahu pembaca. Lagu yang dilantunkan adalah 'Let it Be' bercerita tentang harapan di masa datang. Pasti ada terang, ada cahaya, ada jalan keluar. Artinya musik ini menenangkan bagi jiwa yang gelap.

D. Sudut Pandang 
Muhajir, Analisis Struktural Tiga Cerpen Bertema Virus Korona

Sudut pandang cerita ini adalah orang ketiga terbatas. Narator oleh orang ketiga tetapi cerita diceritakan dari sisi Janitra. Sedangkan tone dan suasana cerita mencekam dan tegang hampir di keseluruhan cerita. Cerita ini memperlihatkan pertengkaran rumah tangga, pemukulan, kata-kata kasar yang dilakukan oleh suami kepada istri.

Hadirnya si kumbang bisa jadi adalah simbolisme dari kemarahan Janitra. Sebuah kemarahan yang dipendam dan diredakan sendiri. Dia memilih mengalah dari pada kedua orang yang dia sayangi terluka.

E. Tema

Tema cerpen ini adalah tentang hubungan suami istri yang tidak seimbang. Relasi yang menyudutkan perempuan. Dalam kondisi ekonomi yang terpuruk karena korona ternyata berdampak besar terhadap keluarga dan pada akhirnya perempuan menjadi pihak yang paling menanggung beban.

\section{SIMPULAN}

Kekhasan atau ciri khusus cerpen bertema korona dapat dilihat dari unsur-nsur pembangun ceritanya. Alur dan sudut pandang tiga cerpen ini sebagai mana cerpen yang lain. Alur menggunakan alur maju, sedangkan sudut pandang dua cerpen menggunakan sudut pandang orang pertama dan satu cerpen menggunakan sudut pandang orang ketiga. Sedangkan yang menjadi kekhasan dapat dilihat dari tiga unsur tokoh, gaya atau tone, tema, dan satire.

Pertama, tokoh. Ketiga cerpen ini menampilkan tokoh yang unik. Cerpen "Jalan Sunyi Menuju Mati” karya Fandrik Ahmad menghadirkan tokoh kelelawar atau kampret. Ia adalah pelaku atau asal-usul menyebarnya sebuah virus. Berbeda lagi dengan cerpen berjudul Apa yang Paul McCartney Bisikkan di Telinga Janitra? Cerpen ini menghadirkan tokoh sebagai makhluk-makhluk yang terdampak dari mewabahnya virus. Berbeda lagi dengan cerpen Simuladistopiakoronakra, ia menghadirkan tokoh yang lebih berbeda. Ia bukan asal usul virus, dan bukan pula manusia terdampak virus tetapi makhluk lain yang kehadirannya ingin menyelamatkan manusia dari virus. 
Kedua, gaya atau tone. Ketiga cerpen bertema korona ini bersuasana seram dan mencekam. Suasana perkelahian, pertengkaran, ceceran darah hadir di semua cerpen yang diteliti.

Ketiga, tema. Dua cerpen bertema tentang keserakahan manusia. Akibat manusia yang serakah, individualis, hilangnya gotong royong, atau tidak mengohormati hak hidup makhluk lain menjadikan kelangsungan hidup manusia sendiri menjadi terancam. Satu cerpen bertema tentang ketimpangan di dalam rumah tangga. Dalam kondisi terdampak wabah, sebuah keluarga yang terancam secara ekonomi maka yang menjadi korban adalah perempuan.

Keempat adalah satire yang digunakan untuk melancarkan kritik terhadap perilaku manusia melalui cara menyindir. Satire bertujuan membuat kondisi berubahnya kesadaran manusia.

\section{REFERENSI}

Ahmad, F. (2020). Jalan Sunyi Menuju Mati. Kompas, p. 10.

Ajidarma, S. G. (2020). Simuladistopiakoronakra. Kompas, p. 10.

Dewi, M. K. (2017). Satire Politik dan Agama dalam Novel Gulliver's Travel oleh Jonathan Swift. Lite: Jurnal Bahasa, Sastra, dan Budaya 13(1), 38-58.

Fananie, Z. (2002). Telaah Sastra. Bandung: Gramedia .

Gotama, S. (2020, 08 02). Apa yang Paul McCartney Bisikan di Telinga Janitra. Kompas, p. 10.

Nurgiantoro, B. (2010). Teori Pengkajian Fiksi. Yogyakarta: Gajah Mada Press.

Soethama, G. A. (2020, 11 15). Belukar Pantai Sanur. Kompas, p. 10.

Stanton, R. (2010). Teori Fiksi. Yogyakarta: Pustaka Pelajar.

Tarigan, H. G. (2008). Menulis sebagai keterampilan berbahasa. Bandung: Percetakan Angkasa.

Teeuw, A. (1984). Sastra dan Ilmu Sastra. Jakarta: Pustaka Jaya.

timdetik.com. (2020). Kapan Sebenarnya Corona Pertama Kali Masuk RI? Jakarta: Detiknews. 